\title{
Exploring the Realization of the American Dream-Taking the Pursuit of Happiness as an Example
}

\author{
Yufei Wang \\ Drama and Film Studies, Hebei University, Shijiazhuang, Hebei Province, 050000, China \\ Corresponding author's e-mail: angela@cas-harbour.org
}

\begin{abstract}
This paper mainly studies the rise and fall of the American dream and the American dream embodied in the pursuit of happiness. This paper has found a lot of kinds of literature, and the research result is that the American dream has two-sided, which can not only make people more confident and work harder to deal with some difficult things but also keep people in the dark. Because the American dream is unrealistic, it cannot be realized in the real world. So this is one of the drawbacks of the American dream that it leaves a huge gap in expectations.
\end{abstract}

Keywords: the American dream, the pursuit of happiness, rising, declines

\section{INTRODUCTION}

Today's culture is diverse. Due to the development of the United States, the increasing number of students studying in the United States, the American dream is mentioned more than often. The American dream once inspired some people to believe that they could achieve a better life through unremitting efforts. Many people even gave up their homeland to come to the United States to show their worth. However, with the development and change of society, the American dream gradually revealed its disadvantages. The main disadvantage is that the American dream shows the opposite of the real life and the rules of the society. For example, the American dream is that if a person works hard, this person will succeed. In fact, this idea is not realistic, because society is diverse, whether success is affected by a number of factors. As one of those movies that most reflect the idea of the American dream, the pursuit of happiness is taken as an example in this paper. In addition, this paper can let people understand the essence of the American dream and its influence on people. So the study basically involves the rise of the American dream, the reason for the rise of the American dream, an understanding of the plot and characters of a movie, a comprehensive view of the American dream and so on. The significance of the study is in a dialectical view of the American dream and a better understanding of the American dream.

\section{THE MEANING OF THE AMERICAN DREAM AND ITS RISING}

\subsection{The meaning of the American dream}

What is the American dream? This concept is often mentioned. In modern society, the narrow sense of the American dream is often understood as: As long as you work hard and don't give up, then you will realize your personal value and have success. The main point of this concept is to rely on their own strength to struggle, rather than relying on the aid of others or on a particular social class. In the common sense, the American dream is the ideal of a democratic, equal and free country. Sometimes we see it as something we want to-and believe we canachieve. Like leave it to beaver, it's like a picture like a bourgeois and nuclear family which reside in the countryside blessedly. This family can reflect people's American dream. Not only that, but we can also see some films certainly in support of the American dream. As the pursuit of happiness, this is a movie about persistence and effort. The meaning is that hard-working people's dreams will eventually come true as long as get through unremitting efforts and they can lead a good life.

\subsection{Reasons for the Rise of the American Dream}

The American dream is a belief widely held by many Americans. It is the mainstream of American cultural values. During the Depression-era of 1931s in America. The American dream was first put forward by James Adams in his epic book of America. 
He wanted to make a better life for all classes of Americans so that they can achieve the American dream, and that was the greatest contribution to the thinking of the world[5]. Since then, the American dream is spreading, and becoming a universal creed for all Americans. However, the rise of the American dream came after the world wars. Unlike the collapse of the European dream, The United States became the most profitable country. The American dream rose at that time, then peaked at the end of the Marshall plan. As the largest economy in the era of globalization, the United States guided the future of globalization[1].

Historically, the gradual maturity of the American dream has gone through three stages of evolution. The first stage is the traditional American dream, or called "Primitive gold rush dream". Most of the people who came to America in the eighteenth century were puritans in England and poor or even bankrupt little farmers in Germany, who were social-economically depressed. But when they came to America where was a colony at that time. They thought the politics of equality is very important. And democracy has also become an area they urgently needed to implement. So at that point, it was established that equal rights are an important component of the American dream. Because at that time, the United States was not rich and relied on traditional agriculture. Therefore, land represented wealth, which meant the more land they have, the happier they are. At the end of the 18th century and the beginning of the 19th century, some people began to seek gold in the United States. Some lucky people became rich overnight by panning for gold, which gave the American dream a strong golden color.

The second stage is called the dream of personal success, and it began to industrialize after the civil war. Immigrants from Europe were increasingly moving into New York, Chicago, and other emerging industrial cities. Such as Edison, who founded general electric through his personal invention. Ford, who invented the automobile production line, Rockefeller, who became rich with the extraction of oil. Many of them were born into poverty but succeeded by their own efforts. In the information age of the 21 st century, Steve Jobs of Apple, Bill Gates of Microsoft and so on became the new wave of the American dream. Their success tells people at that time as long as someone willing to work hard, combined with their own wisdom, no matter how old you are, you can succeed. But at this point, the power of the individual also appears much smaller. Perhaps for reasons related to success stories, everyone agrees on the need to place their own destiny in the hands of the organization in achieving success.

The third stage is called the migration dream. People then saw investing in America as another way to achieve the American dream. What people learned at that time was that someone who wanted to immigrate into the United States only needed $\$ 500,000$. This was the least demanding way to achieve the American dream. The Marriott Hotel project in San Francisco was a good example. This project caused a lot of repercussions in the community. Moreover, in this stage, the American dream was the new value of transcendentalism, emphasizing individual personality and paying less attention to wealth and social status. However, generally speaking, the American dream is too idealized and unrealistic, so the extreme prosperity of the American dream and its decline is an inevitable social phenomenon.

\section{SYNOPSIS}

Hollywood actor Will Smith has been nominated for the best actor at the 79th Academy Awards for his performance in the pursuit of happiness. This film is adapted from a famous American black investment expert Chris Gardern. The story is real, and also shows the American dream. In addition, the main character is a penniless middle-aged man at the bottom of American society. He always carries portable bone-density scanners to sell everywhere for a living, but this machine is too expensive and has little avail, so his family's life always is poor even cannot pay the taxes. It has troubled him for a long time. Also in this stage of leisure time, he accidental contacts the Rubik's cube at his son's birthday and begins to have a strong interest in it. There's a silver lining, the next day on the way to sell, he meets a stockbroker. And yearning the occupation. After his hard work, he signs up and becomes one of the twenty interns, because of a chance: he is impressed by Mr. Twistle because of his success in turning the Rubik's cube into a six-sided cube to successfully win the stock investment company's internship. However, in the night, he is told his wife will leave him, it is a blow to him undoubtedly. And he and his son move to a motel. Once by chance, Chris tells his son that one should decides by itself what it wants to be, even if the others think it is impossible.

When he is an intern at the company, he always feels underrated and under-appreciated. He keeps calling because he wants to be hired. Even he does not hang up the phone in between calls and does not have the time for drinking water. Luckily, he quickly sells all the medical equipment he has left for the rest of the day and is able to keep the house running. At that time, But a huge turnaround has occurred. The government deducts his expenses without warning, causing his bankruptcy. Even worse, he cannot stay in a motel with his son instead of shelters, even men's bathroom. Luckily, he sells the last machine. And he basically maintains the expenses of his son and himself, and passes the exam with first place, stands out among twenty interns and attain his wishes, becomes a stockbroker. And respected by the people. At the end of the film, the film introduces us: After beginning his career at Dean Witter, Chris goes on to found a company in 1987. And then, he sells most of the holdings of his company about multi million dollars. 


\section{ANALYSIS ON THE AMERICAN DREAM IN THE PURSUIT OF HAPPINESS}

\subsection{Character personality}

Inevitably, the character will be a key factor in the American dream. Different from previous American inspirational films featuring monotonous individual success and individual freedom, the strong affection between the characters in the pursuit of happiness contains the excellent personality of the main character, which makes the film closer to the American dream pursued by the American public. The film abandoned the previous American commercial films lofty fantasy, and focus on the expression of the American dream[2]. Chris is a normal lower-class American who raise a family. Though clever as he is, limited opportunities often make his family very poor. So it's a reflection of the poorest people in the United States at the time, more interconnected or representative. For a long time, Americans believed that the necessary prerequisite for the realization of the American dream was perseverance, willingness, and diligence. The main character of this movie, Chris, also believes it. So he and his wife spend a lot of money on machines because they think they can make a lot of money and make a good living by selling them. However, the reality is that no matter how hard he tries to sell these machines, he cannot change the poverty of his family. Even so, he never complains about life. Instead, he gathers all strength to overcome adversity and teach by personal example as well as verbal instruction. After a hard time getting an internship, though, among the twenty interns, he was the one with the lowest education and faced great pressure from life[3]. He yearns for opportunities and cherishes it. $\mathrm{He}$ sells portable bone-density scanners every day for the rest of the day. Not only that but also he never really gives up for a moment, which shows his perseverance. When he interviews, the interviewer also remembers him for his perseverance. Because he could hold the machine downstairs all day. After he discovered the job called stockbroker, neither a place to live, an unpaid internship, nor his wife's departure changed the pursuit of his dream.

\subsection{The American Dream Embodied in the Film}

First of all, the happiness outside the nursery wall is not a deliberate error, but the author of the film has replaced the $\mathrm{Y}$ with the I. Even though the story is set because he is poor, so Chris has to send his son to the cheapest nursery, So the educational resources of the school are not very good, but the author has a deeper meaning in it. He tells him:" There is no ' $\mathrm{Y}$ ' in happiness, there is ' $\mathrm{I}$ '." which means no "why", but "I". The phrase symbolizes the American dream, showing us that there is no reason to fail or persevere in the pursuit of the American dream, and the matters are what you do, what you dream and what you desire. These are the reasons to stick with the American dream.

Second, the American dream is very much embodied in the soundtrack, and Lord, don't move that mountain can be an example here. It sings "Lord don't move that mountain, give me the strength to climb it." Teaching us if you want to help somebody, teaching them how to fish is better than giving him fish. What you want depends on your own efforts to get. It's also an expression of the American dream, which means that people want to be able to achieve their dreams on their own, not based on a particular person or something.

The third is when Chris learns that his wife and son are going to leave him. It is right then that he starts thinking about Thomas Jefferson and the Declaration of Independence, and the part about our right to life, liberty and the pursuit of happiness. He believes that happiness is preceded by the word "pursuit" because it is difficult to achieve. But this plot also makes the audience feel that Chris is pursuing freedom and equality, and he wants to pursue happiness. And what he thinks is the American dream.

\section{EXPLORING THE VICISSITUDES OF THE AMERICAN DREAM}

The American dream is distorted and disillusioned by the great development of the capitalist industry. The results of a survey of the personal experiences of managers of large corporations conducted in the 1920s: Among the 190 managers surveyed, only $3 \%$ came from the poor in American society. Moreover, successful managers are supposed to be white anglo-Saxons of well-educated, upper-middle-class descent, it is too far from the American dream of hard work and success. This is a huge blow to the American dream. It also announces the end of the American dream in real life[4]. Inevitably, there are other labels on the American dream. For example: too idealistic, not realistic.

\subsection{Economic Reasons}

Due to the war and the scientific and technological revolution, the American economy developed a lot Nevertheless, after the great depression, the American economy was much weaker than before. At that time, a lot there were thousands of poor people without jobs in America. Except, for this reason, the gap between the rich and the poor in American society was still widening at that time, and the distribution of social wealth was uneven Americans at the bottom of the society were greatly affected, some people even lost their jobs. How to describe economic development? How to describe the American dream? So at this point, the American dream began to unravel. 


\subsection{Political Reasons}

After Obama's re-election, the American dream is falling apart. The American dream is underpinned by freedom and economic markets. If Without freedom and economic markets, people cannot better pursue freedom. If people change their policies and impose high taxes on the rich, they are actually doing the poor a disservice. This is ostensibly to raise taxes on the rich. For example, if someone raises taxes on the rich, jobs will become harder to find and more people will be unemployed. Even when they are employed, they are exploited by the upper echelon. In this aspect, the poor pay for the measure.

\subsection{Historical Reasons}

About a decade after the end of the first world war in 1918, the great depression of 1929 had not yet arrived. Traditional Puritan morality had fallen apart, and people's hedonism began to spread. These people who have lived through life and death believe that life should be lived on time. So the American dream that everyone once believed in has been eroded away. So as Fitzgerald said:" This is an age of wonder, an age of art, an age of extravagance, and age of mockery." The trauma of history has made people more appreciate the value of life, and the American dream, which needs to be achieved through hard work, has been gradually abandoned.

\subsection{Social Reasons}

The realization of the American dream is the pursuit of a better life. The premise of the realization of the American dream is that everyone has an opportunity. They are equally judged by people, when they are taking a job interview, when they are applying for the university. They are not subjected to their financial situation and family background. If an opportunity is not equal, how can people believe that the American dream is real?

\section{SUGGESTIONS}

From the above point of view. There are two sides to the American dream. Two sides are needed to learn as precisely as possible, then take its essence, discard its dregs for our own use.

The advantage of the American dream lies in certain conditions. It indeed can make people full of hope for their dreams, and have the motivation to realize it. Finally, realize their original dreams. There is no doubt that such thinking has made many people more optimistic. They seek jobs actively and devote themselves to the career which they love. They're like Chris in the pursuit of happiness, Forrest Gump in forrest gump. Determining to survive and live well in America, which has nurtured many well-known people to realize their dreams. Instead of being a mindless salted fish as before, which doing meaningless things every day and having fun doing them. Or depending on the help of others, certain social classes and so on. Because of the emergence of the American dream. It does no matter what age, race or gender you are. Up to the United States government, down to the American homeless. There is a positive trend in this dream-filled place. As we know the statue of liberty, and the declaration of independence both represent the American dream. Even because of the American dream, many people come here to realize their dreams in this promising land. At the same time, when Americans realized their dreams, it also promoted the economic, social and cultural development of the United States to a great extent, making unprecedented breakthroughs in various fields. There are also many successful people, such as former American President: John f. Kennedy; The 44th President of the United States: Barack Hussein Obama, Hollywood actress Marilyn Monroe.

But according to the essence of the American dream. It also has some disadvantages, such as the idealization. The American dream emphasizes that as long as people try their best, they can save themselves from poverty and achieve happiness, no matter which social class they come from. However, from the perspective of reality, people are strongly affected by their origin families and the surroundings. Whether hard-working can help people change from a lower social class to a higher one, also depends on many external factors.In other words, efforts are important, but they are not the only thing that succeed calls for. Therefore, if people do not think carefully, it is easy to make them misunderstand and be disappointed.. In fact, in the early stage, even with the help of policy, the poor were exploited by the rich under the appealing of the American dream. Hence, the American dream is misleading and even can be seen as a trap for cheap labour force.

So sometimes people have great expectations to pursue their dreams but do not come true, it is inevitable that there will be some disappointment, and they will even doubt themselves. There are a lot of examples of failure, such as the most classic movie called the great gatsby. Showing that the American dream will not come true in real life, and finally lay the foundation for the disillusionment of the American dream.

So what is important is that the American dream is idealized, and it's not $100 \%$ achievable in real life. But look at it another way, the American dream is one of those things that we have to learn from is 'Positive'. Just like the hero in the pursuit of happiness. If he did not have the American dream in his heart and the family he loved, he would not seek a job as a stock investor, nor through a day without water to get a position, and temporarily give up his wife. Comprehensive the film and the background at that time, His efforts also proved to us an important mindset if someone want to succeed. He has to be hard on himself. And no matter what difficulties cannot stop us forward steps, he should firm the confidence until the end, because possibly that is god give him tests before making him successful. As for if he can succeed or not, he need to 
create opportunities for himself better, find the right way and so on.

\section{CONCLUSION}

The main purpose of this paper is to analyze the American dream at a deeper level by describing the pursuit of happiness. And explain the strengths and weaknesses of the American dream. Through this paper, the American dream has motivated many Americans to pursue their dreams. Even made America more positive, Whereas, the American dream is unrealistic. As a result, in the real world, it is impossible to exist. But this paper only analyzes the American dream from the perspective of the pursuit of happiness, whereas it doesn't describe other movies about the American dream. Therefore, the viewpoint of this paper is a little single relatively. It will be better if more movies reflected the American dream are analyzed. Therefore, in the future study, the author will analyze the American dream from other aspects and then a deeper analysis and a better understanding of the American dream can be obtained.

\section{ACKNOWLEDGMENT}

First and foremost, I would like to show my deepest gratitude to my teachers and professors in my university, who have provided me with valuable guidance in every stage of the writing of this thesis. Further, I would like to thank all my friends and roommates for their encouragement and support. Without all their enlightening instruction and impressive kindness, I could not have completed my thesis.

\section{REFERENCES}

[1] Y. Ji, D. Zhang, R. Yang, et al. The collapse of the modern Chinese dream and the rise of the European dream and the American dream. Civilization. 2013, vol.11, pp. 45-53.

[2] X. Zheng. The American dream culture in the pursuit of happiness. Film Literature. 2013, vol.10, pp. 33-56.

[3] W. Chang. The embodiment of the American dream in the pursuit of happiness. Grain in Ear. 2013, vol.13, pp. 156-180.

[4] C. Ju. Explore the evolution of the American dream. The Science Education Article Collects. 2011, vol.26, pp. 120-132.
[5] J. T. Adams. The epic of America.New York: Greenwood Press Reprint. 1931, pp. 221-236. 